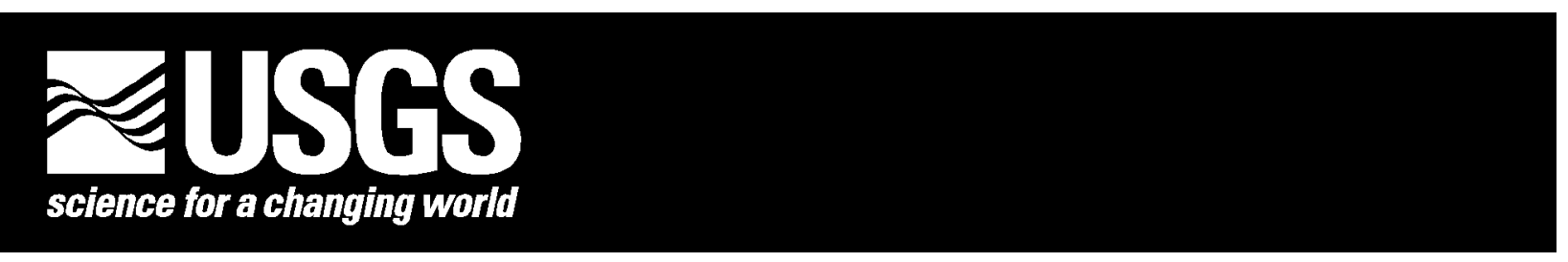

\title{
Analytical methods utilized by the United States Geological Survey for the analysis of coal and coal combustion by-products
}

\author{
by \\ John H. Bullock, Jr. ${ }^{1}$, James D. Cathcart ${ }^{1}$, and William J. Betterton ${ }^{1}$
}

Open-File Report 02-389

2002

This report is preliminary and has not been reviewed for conformity with U.S. Geological Survey editorial standards or with the North American Stratigraphic Code. Any use of trade, firm, or product names is for descriptive purposes only and does not imply endorsement by the U.S. Government.

\section{U.S. DEPARTMENT OF THE INTERIOR}

U.S. GEOLOGICAL SURVEY

${ }^{1}$ U.S.Geological Survey, Denver, Colorado 


\section{ANALYTICAL METHODS UTILIZED BY THE UNITED STATES GEOLOGICAL SURVEY FOR THE ANALYSIS OF COAL AND COAL COMBUSTION BY-PRODUCTS}

\section{Introduction}

The U. S. Geological Survey's (USGS) Energy Analytical Laboratory was established in 1995. The laboratory is located in Lakewood, Colorado, and is an integral part of the Energy Resources Program (ERP). The ERP is responsible for conducting domestic and international research to improve the understanding of the geologic occurrence, formation, and evolution as well as the utilization of oil, gas, and coal resources. In support of this objective, the Energy Analytical Laboratory provides a wide spectrum of chemical analyses of major, minor, and trace elements in energy related commodities and utilization by-products. These analyses are in support of projects that: 1) assess the quality of energy commodities and, 2) provide information to minimize the environmental impact of energy extraction and utilization. Examples of supported ERP studies include:

A) Characterization of the distribution of various elements in coal and their modes of occurrence in support of the development of geologic models of coal quality parameters,

B) Investigations of elemental contents in coal feed stocks and related coal combustion by-products in power plants,

C) Mobilization of elements in acid mine drainage (AMD),

D) Evaluations of potential environmental hazards of produced waters (eg. coal bed methane waters), in conjunction with oil and gas production.

Coal quality assessments are important in identifying the concentrations and distributions of sulfur and critical trace elements as described by the 1990 Clean Air Act Amendments (U.S. Statutes at Large, 1990).

This report briefly describes how a sample is processed (figure 1). The following is an overview of sample submittal procedures, sample preparation techniques, and physical 
and chemical methodologies used by the Energy Analytical Laboratory to analyze coal and coal combustion by-products. Previous summaries of analytical methods and sample collection procedures used by the USGS include Swanson and Huffman (1976) and Golightly and Simon (1989).

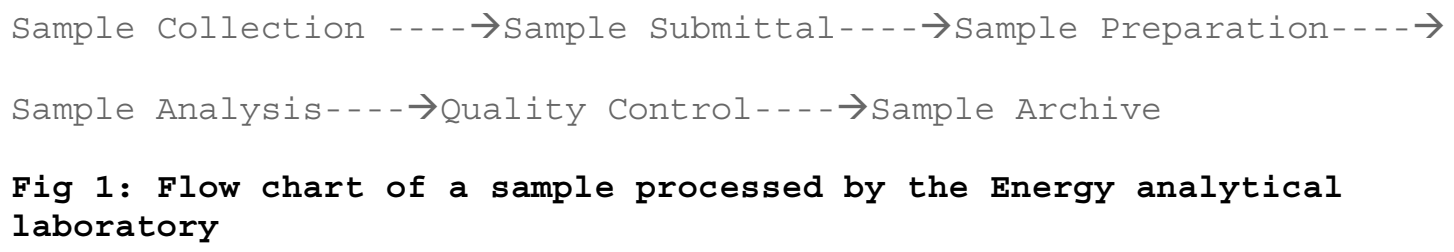

\section{Sample Submittal}

Sample collection will not be discussed in this fact sheet because it is not generally the responsibility of the Energy Analytical Laboratory, however, coal sampling is extremely important and the procedures described in Stanton (1989) are highly recommended. After sample collection is complete, the scientist submits the samples to the laboratory for processing. Required collection information includes: submitter name, address, phone number, email address, project number and title, sample type, number of samples, type of analysis requested, sample field number, geographic coordinates (latitude/longitude), state and county or country, formation name (if known), geologic age (if known), and source and representativeness of the sample (Murphy and Mendes, 1993; Christie and others, 1993). A sample description field is included for any additional relevant information, such as coal seam thickness or mine name.

For processing and analysis, the samples must be divided into lots (jobs) of forty samples or less. Each sample should be between 100 - 150 grams (g) in size. Sample randomization, duplication, or the addition of blind standards by the submitter are encouraged, but not required.

\section{Sample Preparation}

Most samples of coal and coal combustion by-products require some kind of physical preparation prior to chemical analysis. This preparation helps to increase the sample 
surface area which enhances the efficiency of chemical attack. Sample preparation also aids in the homogenization of the sample to ensure that the sub-sample analyzed is representative of the entire sample (Taylor and Theodorakis, 1993). Each coal sample is reduced to $0.5 \mathrm{~cm}$ fragments in a jaw crusher and pulverized to - 60 mesh in a Braun vertical pulverizer. Two splits are made for each sample using a Jones splitter; these are put into three-ounce cardboard containers. One split is ashed for methods requiring coal ash analyses. A second split is used for methods requiring whole coal analyses and for sample archive. A sub-split of the second split is put into a capped $20 \mathrm{ml}$ high-density polyethylene liquid scintillation vial to prevent residual moisture loss or gain prior to analysis.

\section{Moisture}

Results of analyzed coal samples in this laboratory are reported on an "as-determined" basis as described in American Society for Testing and Materials (ASTM) method D3180 (ASTM, 2002). Moisture content of the "as-determined" samples is necessary for the submitter to calculate the analytical results to a moisture free or "dry" basis. Moisture is determined by establishing the loss of weight of a sample when heated under rigidly controlled conditions.

The moisture in the coal sample is determined using ASTM method D-3173 (ASTM, 2002). One gram of coal is put in a weighed $20 \mathrm{ml}$ ceramic capsule with lid and reweighed. The moisture is then determined by heating the sample in a preheated forced air furnace, using air dried to a dew point less then $-10^{\circ} \mathrm{C}$, at $107 \pm 3^{\circ} \mathrm{C}$ for one hour, cooled in a desiccator, reweighed, and then discarded.

The calculation of percent moisture is as follows:

$$
\text { Moisture }(\%)=((\mathrm{A}-\mathrm{B}) / \mathrm{A}) \times 100
$$


where "A" is the "as determined" weight of the sample before heating and "B." is the "dry" weight of the sample after heating to $107^{\circ} \mathrm{C}$. Note: all weights are determined with the lid on.

\section{Coal Ash}

Ashing improves analysis sensitivity and accuracy by concentrating the elements in a coal sample for analysis, expediting the dissolution of coal, and removing the chemical interferences of the organic matter. Ash yield is determined by weighing the residue remaining after burning a coal sample under rigidly controlled conditions.

For most coal samples received by the laboratory, the ash content is determined by a modification of the USGS method by Walthall and Fleming (1989). Approximately 50.0 $\mathrm{g}$ of coal is put in a weighed $90 \mathrm{ml}$ ceramic dish and reweighed. The ash is then determined by heating the sample in a forced air furnace (creating a desiccant type environment), using air dried to a dew point less then $-10^{\circ} \mathrm{C}$, with the following thermal profile: (1) ramp from room temperature to $200^{\circ} \mathrm{C}$ at $2.5^{\circ} \mathrm{C} / \mathrm{min}$., hold for $1.5 \mathrm{hrs}$; (2) ramp from $200^{\circ} \mathrm{C}$ to $350^{\circ} \mathrm{C}$ at $2.5^{\circ} \mathrm{C} / \mathrm{min}$., hold for $2 \mathrm{hrs}$; (3) ramp from $350^{\circ} \mathrm{C}$ to $525^{\circ} \mathrm{C}$ at $2.5^{\circ} \mathrm{C} / \mathrm{min}$., hold for $36 \mathrm{hrs}$; (4) turn off the furnace and allow the sample to cool down to room temperature in the furnace. After reweighing and recording the weight, the cooled, ashed coal sample is stored in a three-ounce cardboard container.

For anthracite or coke samples, ash is determined using a variation of ASTM method D-3174 (ASTM, 2002). This method is used to ensure complete ashing of the higher rank coals. The procedure is similar to the method above except for the thermal profile which is as follows: (1) ramp from $0^{\circ} \mathrm{C}$ to $750^{\circ} \mathrm{C}$ at $2.5^{\circ} \mathrm{C} / \mathrm{min}$., hold for $2 \mathrm{hrs}$; (2) turn off the furnace and allow the sample to cool down to room temperature in the furnace. After reweighing and recording the weight, the cooled, ashed coal sample is stored in a threeounce cardboard container.

The calculation of percent ash is as follows:

$$
\operatorname{Ash}(\%)=(\mathrm{C} / \mathrm{A}) \times 100
$$




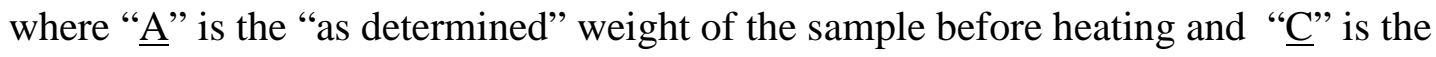
weight of the inorganic residue after ashing.

\section{Mercury}

Mercury is determined in whole coal and coal combustion by-products by digesting $0.15 \mathrm{~g}$ of sample with nitric acid, sulfuric acid, and vanadium pentoxide in a disposable glass test tube (O'Leary, 1994). After digestion, samples are diluted with deionized water to a constant volume. The samples are then mixed with air, and a solution of sodium chloride, hydroxylamine hydrochloride, and sulfuric acid. The $\mathrm{Hg}^{+2}$ is then reduced to $\mathrm{Hg}^{\mathrm{o}}$ with a stannous chloride solution in a continuous flow manifold (Kennedy and Crock, 1987). The elemental mercury vapor is separated using a phase separator and concentration is measured using cold vapor-atomic absorption spectrometry (CVAAS). Samples containing silver $>12 \mathrm{ppm}$, gold $>10 \mathrm{ppm}$, or selenium $>25 \mathrm{ppm}$ will interfere and need to be diluted and reanalyzed. Approximately 40 samples (including blanks, reference standards, and duplicates) can be analyzed per day. The lower reporting limit for this method is $0.02 \mathrm{ppm}$. On average, the relative standard deviation (\% RSD) on references materials using this method is $10 \%$. This method was approved by ASTM in 1999 as standard D-6414 (ASTM, 2002).

\section{Selenium}

For determinations of selenium, there are different digestion procedures for coal and coal combustion by-products (Hageman and Welsch, 1996). Coal samples $(0.10 \mathrm{~g})$ are digested using a combination of sulfuric, nitric, and perchloric acids in an open Erlenmeyer flask. Coal combustion by-products $(0.25 \mathrm{~g})$ are digested using nitric, hydrochloric, perchloric, sulfuric, and hydrofluoric acids in an open $30 \mathrm{ml}$ Teflon vessel. The digested sample solutions are transferred to $60 \mathrm{ml}$ polyethylene bottles and brought up to $55.0 \mathrm{~g}$ with deionized water. In the analytical stream, a sodium borohydride 
solution is added to the sample solutions, which reduces $\mathrm{Se}^{+4}$ to $\mathrm{Se}^{0}$. The resulting gaseous selenium hydride is stripped from the analytical stream with a phase separator and transported with nitrogen to the atomizer (a quartz tube furnace heated to $2000^{\circ} \mathrm{C}$ by an air acetylene flame) of the atomic absorption spectrophotometer. Selenium concentration is determined using calibration standards in solutions with similar matrices. Interferences can occur if $500 \mathrm{ppm}$ or more of $\mathrm{Cu}, \mathrm{Fe}, \mathrm{Ni}$, and $\mathrm{Sn}$ are present in the sample. Approximately 50 samples (including blanks, reference standards, and duplicates) can be analyzed per day. The lower reporting limit for this method is 0.1 ppm. On average, the relative standard deviation (\% RSD) on references materials using this method is $10 \%$.

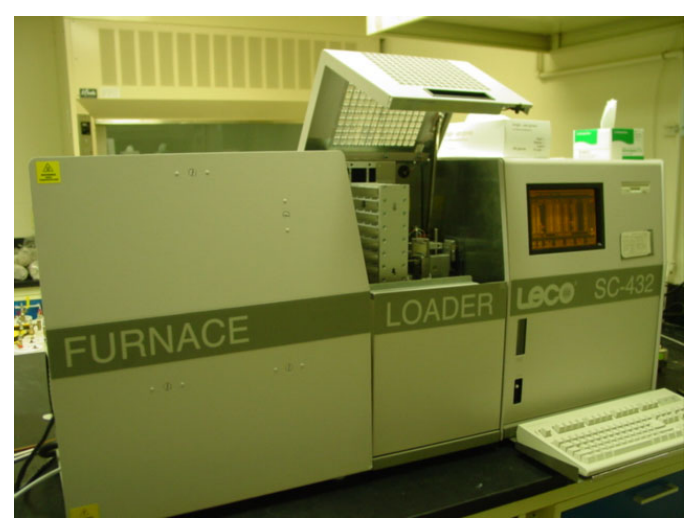

Figure 2. LECO SC-432 for the analysis of total sulfur in coal and coal combustion by-products.

\section{Total Sulfur}

Approximately $0.25 \mathrm{~g}$ of coal is weighed into a ceramic combustion boat and burned in a tube furnace (figure 2) at a temperature of $1350{ }^{\circ} \mathrm{C}$ in a stream of high purity oxygen to oxidize the sulfur. For samples of coal ash and coal combustion by-products, ASTM D5016 (ASTM, 2002) recommends the use of a promoting agent (eg. COM-CAT ${ }^{\mathrm{TM}}$, vanadium pentoxide) to assist in the combustion process. One gram of a promoting agent should be mixed in the combustion boat with approximately $0.25 \mathrm{~g}$ sample (LECO 
Corporation, 1998). Moisture and particulates are removed from the gas stream by traps filled with glass wool and anhydrous magnesium perchlorate. The gas stream is then passed through a cell where sulfur dioxide content is measured by an infrared (IR) absorption detector. The instrument must be calibrated using sample reference materials (SRM's) such as those supplied by the National Institute of Standards and Technology (NIST). Approximately 50 samples (including blanks, reference standards, and duplicates) can be analyzed per day. The lower reporting limit for this method is $0.05 \%$ (Curry, 1993). On average, the relative standard deviation (\% RSD) on references materials using this method is $5 \%$.

\section{Chlorine in coal}

Chlorine in coal is determined utilizing a sample decomposition technique using Eshka's mixture (two parts magnesium oxide and one part sodium carbonate), followed by an ion chromatographic determination (Gent and Wilson, 1985). A $0.10 \mathrm{~g}$ coal sample is weighed into a Ni-Cr crucible, mixed with Eshka's mixture and put into a furnace at room temperature. The temperature of the furnace is ramped up to $400^{\circ} \mathrm{C}$ at $10^{\circ} \mathrm{C} / \mathrm{min}$. The furnace remains at this temperature for 30 minutes. Ramping then continues at $10^{\circ} \mathrm{C} / \mathrm{min}$ until a final temperature of $675^{\circ} \mathrm{C}$ is reached. The furnace remains at this temperature for seven hours. The sample is removed from the furnace, cooled, and diluted for analysis with $50 \mathrm{ml}$ of deionized water. Approximately 25 samples (including blanks, reference standards, and duplicates) can be analyzed per day. The lower reporting limit for this technique is $0.015 \%(150 \mathrm{ppm})$. On average, the relative standard deviation (\% RSD) on references materials using this method is $15 \%$. 


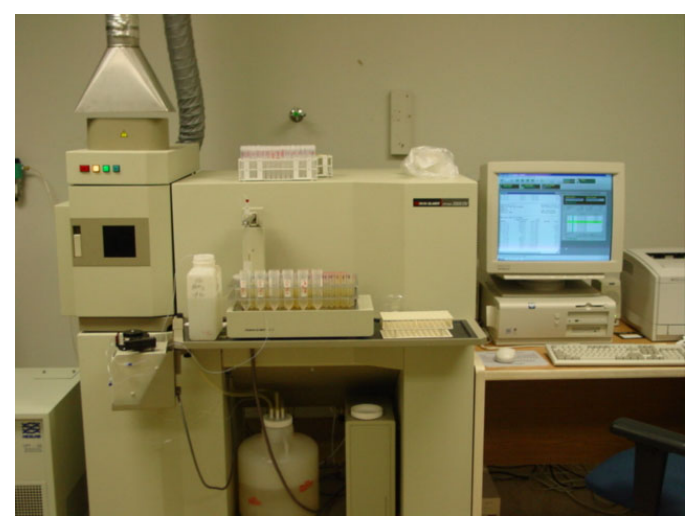

Figure 3. Perkin-Elmer's Optima 3300DV ICP-AES for multi-element analysis of coal ash and coal combustion by-products.

\section{Multi-element analysis by ICP-AES and ICP-MS}

Fifty-nine major, minor, and trace elements are determined using a combination of inductively coupled plasma-atomic emission spectrometry (ICP-AES, figure 3) and inductively coupled plasma-mass spectrometry (ICP-MS) on coal ash samples and coal combustion by-products prepared using both a multi-acid and a sodium peroxide sinter decomposition technique (Meier and others, 1996). The multi-acid decomposition is used in the determination of 31 elements (Crock and others, 1983); the remaining elements are determined following a sodium peroxide sinter decomposition technique (modification of Borsier and Garcia, 1983). The ICP-AES is calibrated with a series of multi-element solution standards. The ICP-MS is calibrated with several digested geologic standards. ICP-AES interferences may result from spectral interferences, background shifts, and matrix effects (Thompson and Walsh, 1983). Multi-Spectral Fittings (MSF) and background corrections are applied using proprietary data system software (Perkin-Elmer, 1997). ICP-MS interferences come from matrix effects, instrumental drift, and isobaric overlap of some elemental isotopes and molecular ions. The isotopes measured are selected to minimize isobaric overlap from other elements. Approximately 25 samples (including blanks, reference standards, and duplicates) can be prepared daily for each decomposition technique. Tables 1 and 2 show the elements 
analyzed, the decomposition technique used, their reporting limits and their average relative standard deviation .

Table 1 - Elements analyzed, reporting limits, relative standard deviation, and decomposition technique of coal combustion residues by ICP-AES

$S=$ sinter, $\quad M=$ multi-acid

\begin{tabular}{|c|c|c|}
\hline & $\begin{array}{l}\text { Reporting Limit } \\
\text { (pom unless note }\end{array}$ & $\begin{array}{c}\text { Relative Standard } \\
\text { Deviation (\%) }\end{array}$ \\
\hline
\end{tabular}

$\begin{array}{lcrc}\text { Aluminum } & 0.02 \% & 5 & \mathrm{~S} \\ \text { Calcium } & 0.02 \% & 4 & \mathrm{~S} \\ \text { Iron } & 0.02 \% & 4 & \mathrm{~S} \\ \text { Magnesium } & 0.02 \% & 5 & \mathrm{~S} \\ \text { Phosphorus } & 0.02 \% & 7 & \mathrm{~S} \\ \text { Potassium } & 0.02 \% & 7 & \mathrm{~S} \\ \text { Silicon } & 0.02 \% & 5 & \mathrm{~S} \\ \text { Sodium } & 0.01 \% & 5 & \mathrm{M} \\ \text { Sulfur } & 0.02 \% & 10 & \mathrm{~S} \\ \text { Titanium } & 0.02 \% & 5 & \mathrm{~S} \\ \text { Barium } & 2 & 6 & \mathrm{~S} \\ \text { Beryllium } & 1 & 5 & \mathrm{M} \\ \text { Boron } & 20 & 19 & \mathrm{~S} \\ \text { Chromium } & 2 & 10 & \mathrm{M} \\ \text { Cobalt } & 2 & 5 & \mathrm{M} \\ \text { Copper } & 2 & 6 & \mathrm{M} \\ \text { Lithium } & 4 & 5 & \mathrm{M} \\ \text { Manganese } & 2 & 5 & \mathrm{M} \\ \text { Nickel } & 4 & 5 & \mathrm{M} \\ \text { Scandium } & 4 & 5 & \mathrm{M} \\ \text { Strontium } & 1 & 3 & \mathrm{M} \\ \text { Thorium } & 8 & 10 & \mathrm{M} \\ \text { Vanadium } & 2 & 5 & \mathrm{M} \\ \text { Yttrium } & 1 & 8 & \mathrm{M} \\ \text { Zinc } & 4 & 6 & \mathrm{~S} \\ \text { Zirconium } & 5 & 9 & \end{array}$


Table 2 - Elements analyzed, reporting limits, relative standard deviation, and decomposition technique of coal combustion residues by ICP-MS*

$S=$ sinter, $\quad M=$ multi-acid

\begin{tabular}{|c|c|c|}
\hline & $\begin{array}{l}\text { Reporting Limit } \\
\text { In ppm }\end{array}$ & $\begin{array}{c}\text { Relative Standard } \\
\text { Deviation (\%) }\end{array}$ \\
\hline
\end{tabular}

\begin{tabular}{|c|c|c|c|}
\hline Antimony & 0.1 & 8 & $M$ \\
\hline Arsenic & 0.2 & 7 & M \\
\hline Bismuth & 0.1 & 12 & M \\
\hline Cadmium & 0.1 & 20 & $M$ \\
\hline Cerium & 3 & 7 & $\mathrm{~S}$ \\
\hline Cesium & 0.1 & 20 & $\mathrm{M}$ \\
\hline Dysprosium & 0.2 & 7 & $S$ \\
\hline Erbium & 0.2 & 7 & $S$ \\
\hline Europium & 0.2 & 7 & $S$ \\
\hline Gadolinium & 1 & 8 & $S$ \\
\hline Gallium & 0.1 & 8 & $\mathrm{M}$ \\
\hline Germanium & 0.1 & 10 & $\mathrm{M}$ \\
\hline Gold & 10 & -- & $\mathrm{M}$ \\
\hline Hafnium & 1 & 9 & $S$ \\
\hline Holmium & 0.5 & 6 & $S$ \\
\hline Lanthanum & 2 & 7 & $\mathrm{~S}$ \\
\hline Lead & 0.5 & 10 & $\mathrm{M}$ \\
\hline Molybdenum & 0.2 & 4 & $M$ \\
\hline Neodymium & 2 & 6 & $\mathrm{~S}$ \\
\hline Niobium & 0.1 & 10 & $\mathrm{M}$ \\
\hline Praseodymium & 0.5 & 7 & $\mathrm{~S}$ \\
\hline Rubidium & 0.1 & 20 & $M$ \\
\hline Samarium & 0.5 & 6 & $\mathrm{~S}$ \\
\hline Silver & 2 & -- & $\mathrm{M}$ \\
\hline Tantalum & 1 & 10 & $\mathrm{~S}$ \\
\hline Tellurium & 0.1 & 15 & $\mathrm{M}$ \\
\hline Terbium & 0.5 & 7 & $\mathrm{~S}$ \\
\hline Thallium & 0.1 & 9 & $M$ \\
\hline Thulium & 0.5 & 8 & $\mathrm{~S}$ \\
\hline Tin & 3 & 8 & $\mathrm{M}$ \\
\hline Tungsten & 1 & 9 & $\mathrm{~S}$ \\
\hline Uranium & 0.1 & 8 & $\mathrm{M}$ \\
\hline Ytterbium & 0.5 & 7 & $\mathrm{~S}$ \\
\hline
\end{tabular}

* Samples prepared using the sinter decomposition technique require laboratory manager approval prior to analysis by ICP-MS. 


\section{Quality Control}

For each method, samples are run in "batches": one or more jobs forming a group of 30 to 50 samples digested together. Each batch contains at least one method blank sample, three standard reference materials, and at least one digestion duplicate sample.

A method blank contains similar chemicals and goes through the digestion process, but does not contain the "sample" (coal or ash) constituent. The variability or the standard deviation (s) of the method blank is used for estimating the lower reporting limit for each element (Arbogast, 1996). This laboratory uses a value of five times the standard deviation (5s) for its reporting limit. The standard deviation is determined by analyzing at least three blank samples run on three nonconsecutive days.

A reference material should be stable and sufficiently well characterized to be used for the calibration of an analytical instrument, the assessment of a measurement method, or for assigning values to a material (ASTM, 2002). It is highly recommended that at least one of the analytical standards be a certified reference material from an organization recognized worldwide, such as the National Institute of Standards and Technology (NIST). The certified reference materials should have a similar matrix and be processed by the same digestion procedure as the unknown samples. The results of these materials reflect upon the effectiveness of the digestion and the operation of the analytical instrumentation. A bias in the data can be normalized using the results of the certified reference materials.

A digestion duplicate is an unknown sample that is weighed out twice, with each sample going through the digestion process. Each duplicate is then run on the analytical instrumentation. Comparison of the results will help determine the precision of the digestion process in the method and/or the homogeneity of that sample.

Quality control data, used by the laboratory to ensure data quality, is sent to the submitter as the analyses are completed. For reference materials, observed values, recommended values, and the percent difference between them is reported. For duplicate samples, both values, their mean, and the percent difference are given. 


\section{Sample archive and storage}

After samples have been analyzed for all methods requested, the remainder of the whole coal and coal ash splits, along with the archive split, are placed in temporary storage for $1-2$ years. This allows the submitter time to analyze the data and to request any additional or follow-up analyses. The samples are then moved to permanent storage.

\section{Bibliography}

American Society for Testing and Materials, 2002, Annual Book of ASTM Standards 2002, v. 05.06, 650 p.

Arbogast, Belinda F., 1996, Analytical Methods for the Mineral Surveys Program: U.S. Geological Survey Open-File Report 96-525, p. viii-x.

Borsier, M. and Garcia, M., 1983, Analyse automatique d'echantillons geologiques par plasma ICP: Spectrochimica Acta, v. 38B, nos. 1/2, p. 123-127.

Christie, J.H., Jackson, L.L., and Sutton, A.L., 1993, Submittal of requests for analysis to the Branch of Geochemistry using a spreadsheet program: U.S. Geological Survey Internal Documentation BGC930430A (paper copy), 22 p., BGC930430B (one disk).

Crock, J.G., Lichte, F.E., and Briggs, P.H., 1983, Determination of elements in National Bureau of Standards geological reference materials SRM 278 obsidian and SRM 688 basalt by inductively coupled plasma-atomic emission spectroscopy: Geostandards Newsletter, v. 7, no. 2, p. 335-340.

Curry, Kenneth Joe, 1993, Total sulfur by combustion, in Arbogast, Belinda F., ed., Analytical Methods for the Mineral Surveys Program: U.S. Geological Survey Open-File Report 96-525, p. 177-181.

Gent, Carol A., and Wilson, Stephen A., 1985, The determination of sulfur and chlorine in coals and oil shales using ion chromatography: Analytical Letters, v. 18, p. 729-740.

Golightly, D.W., and Simon, F.O., ed., 1989, Methods for Sampling and Inorganic Analysis of Coal: U.S. Geological Survey Bulletin 1823, 72 p.

Hageman, Philip L., and Welsch, Eric, 1996, Arsenic and selenium by flow injection or continuous flow-hydride generation-atomic absorption spectrophotometry, in Arbogast, Belinda F., ed., Analytical Methods for the Mineral Surveys Program: U.S. Geological Survey Open-File Report 96-525, p.24-30. 
Kennedy, K.R., and Crock, J.G., 1987, Determination of mercury in geological materials by continuous-flow cold vapor atomic absorption spectrophotometry: Analytical Letters, v. 20 , p. $899-908$.

LECO Corporation, 1998, Instruction Manual: SC-432, SC-432DR, SC432H, SC-432L, Sulfur analyzers, St. Joseph, MO.

Meier, Allen L., Lichte, Frederick E., Briggs, Paul H., and Bullock, John H., Jr., 1996, Coal ash by inductively coupled plasma-mass spectrometry, in Arbogast, Belinda F., ed., Analytical Methods for the Mineral Surveys Program: U.S. Geological Survey Open-File Report 96-525, p. 109-125.

Murphy, C.M., and Mendes, R.V., 1993, Sample Submittal Manual, Fourth Edition, 1993: U.S. Geological Survey Open-File Report 93-533, 40 p.

O'Leary, Richard M., 1994, Mercury in whole coal and biological tissue by continuous flow-cold vapor-atomic absorption spectrometry, in Arbogast, Belinda F., ed., Analytical Methods for the Mineral Surveys Program: U.S. Geological Survey Open-File Report 96525, p. 51-55.

Perkin-Elmer Corporation, 1997, Instruction Manual: ICP WinLab ${ }^{\mathrm{TM}}$ Software Guide, Shelton, CT.

Stanton, Ronald W., 1989, Sampling of coal beds for analysis, in Golightly, D.W., and Simon, F.O., ed., Methods for Sampling and Inorganic Analysis of Coal: U.S. Geological Survey Bulletin 1823, p. 7-13.

Swanson, Vernon, E., and Huffman, Claude, Jr., 1976, Guidelines for sample collecting and analytical methods used in the U.S. Geological Survey for determining chemical composition of coal: U.S. Geological Survey Circular 735, 11 p.

Taylor, Cliff D., and Theodorakis, Peter M., 1993, Rock sample preparation, in Arbogast, Belinda F., ed., Analytical Methods for the Mineral Surveys Program: U.S. Geological Survey Open-File Report 96-525, p. 2-6.

Thompson, M. and Walsh, J.N., 1983, A handbook of inductively coupled plasma spectrometry, p. 16-36.

U.S. Statutes at Large, 1990, Provisions for attainment and maintenance of national ambient air quality standards: Public Law $101-549,101^{\text {st }}$ Congress, $2^{\text {nd }}$ Session, v. 104 , pt. 4, p. 2353-3358.

Walthall, F.G., and Fleming, S.L., II, 1989, Preparation of coal for analysis, in Golightly, D.W., and Simon, F.O., ed., Methods for Sampling and Inorganic Analysis of Coal: U.S. Geological Survey Bulletin 1823, p. 15-19. 


\section{Contact the following people for more information on:}

Energy analytical laboratory methods - John H. Bullock, Jr.

U. S. Geological Survey

P.O. Box 25046, Mail Stop 973

Denver, CO 80225

Phone: 303-236-2496

Fax: 303-236-1983

E-mail: jbullock@usgs.gov

Sample submittal and sample preparation - James D. Cathcart U. S. Geological Survey

P.O. Box 25046, Mail Stop 973

Denver, CO 80225

Phone: 303-236-7780

Fax: 303-236-1983

E-mail: cathcart@usgs.gov

Ashing, moisture, and sample preparation - William J. Betterton U. S. Geological Survey

P.O. Box 25046, Mail Stop 973

Denver, CO 80225

Phone: 303-236-7740

Fax: 303-236-1983

E-mail: wbettert@usgs.gov 
